Journal of Neurology, Neurosurgery, and Psychiatry 1985;48:709-712

Short report

\title{
The value of the measurement of cerebrospinal fluid levels of lysozyme in the diagnosis of neurological disease
}

\author{
G FIRTH, ${ }^{*}$ J REES, $†$ RO MCKERAN $\ddagger$
}

From the Biochemistry* and Neurology $\dagger$ Departments, Hurstwood Park Neurological Centre, Haywards Heath, Sussex and the Neurology $\ddagger$ Department at Atkinson Morley’s Hospital, London, UK

SUMMARY A turbidimetric technique has been adapted to yield maximum sensitivity for the measurement of lysozyme in cerebrospinal fluid. One hundred and ninety-eight patients were studied over a total period of 9 months using this technique. In addition to the considerably elevated levels known to occur in cases of bacterial and fungal meningitis, increased activity was also demonstrated in cases of subarachnoid haemorrhage and in certain inflammatory conditions. Normal or marginally increased levels were seen in cases of viral meningitis and encephalitis.

The partially treated patient with bacterial meningitis and only slightly reduced cerebrospinal (CSF) glucose concentration, the patient with lymphocytic meningitis of undetermined cause, and the patient with tuberculous meningitis and an initially normal CSF continue to pose problems in diagnosis and early appropriate treatment. The availability of additional markers to suggest the presence of an infective agent clearly would be helpful. Elevated levels of CSF lysozyme may represent one such marker since this enzyme is liberated from degenerating polymorpholeucocytes and viable monocytes and macrophages ${ }^{1}$ found in high concentration in the meninges in the different types of bacterial, fungal and granulomatous meningitis. ${ }^{2-s}$ Elevated CSF levels of lysozyme have been described in a number of neurological disorders. ${ }^{67}$ The purpose of this study was to use a more sensitive assay to reassess, the value of this estimation, and to evaluate its specificity and value in following the response to treatment in a wide variety of neurological diseases.

Address for reprint requests: Dr RO McKeran, Neurology Department, Atkinson Morley's Hospital, 31 Copse Hill, Wimbledon, London, SW20 ONE, UK.

Received 10 July 1984 and in revised form 6 November 1984 . Accepted 17 November 1984

\section{Materials}

Micrococcus lysodeikticus (MC) was obtained from Worthington Biochemical Corporation, Freehold, New Jersey, USA. Human lysozyme (isolated from the urine of a patient suffering from monocytic leukaemia) was kindly supplied by Dr Elliott F Osserman, Department of Medicine, Columbia University, USA. All other reagents were supplied by BDH Ltd.

\section{Methods}

CSF samples obtained from patients suffering from a wide variety of neurological diseases were stored at $-20^{\circ} \mathrm{C}$ prior to estimation of the level of lysozyme. Specimens were also obtained from a control group with chronic back pain with no evidence of an inflammatory aetiology undergoing myelography. Lysozyme levels in CSF have been shown to remain stable for up to 4 months, when stored at $-20^{\circ} \mathrm{C}$. 8 Lysozyme was measured by estimating the rate of lysis of a suspension of $M$ lysodeikticus in $0.04 \mathrm{M}$, pH 6.3 sodium phosphate buffer on a Pye Unicam SP1800 spectrophotometer and recorder at a wavelength of $340 \mathrm{~nm}$ over a period of $2 \mathrm{~min}$. Standard preparations of human lysozyme were prepared in a $\mathbf{0 . 0 5} \mathrm{M}, \mathrm{pH} 7.4$ sodium phosphate buffer containing $1 \mathrm{~g} / \mathrm{l}$ gelatin and $170 \mathrm{mg} / \mathrm{l}$ sodium merthiolate, since it has been shown that standard solutions prepared in aqueous buffer containing no protein rapidly lose activity owing to binding of the enzyme to the walls of the vessel. $^{8}$ 


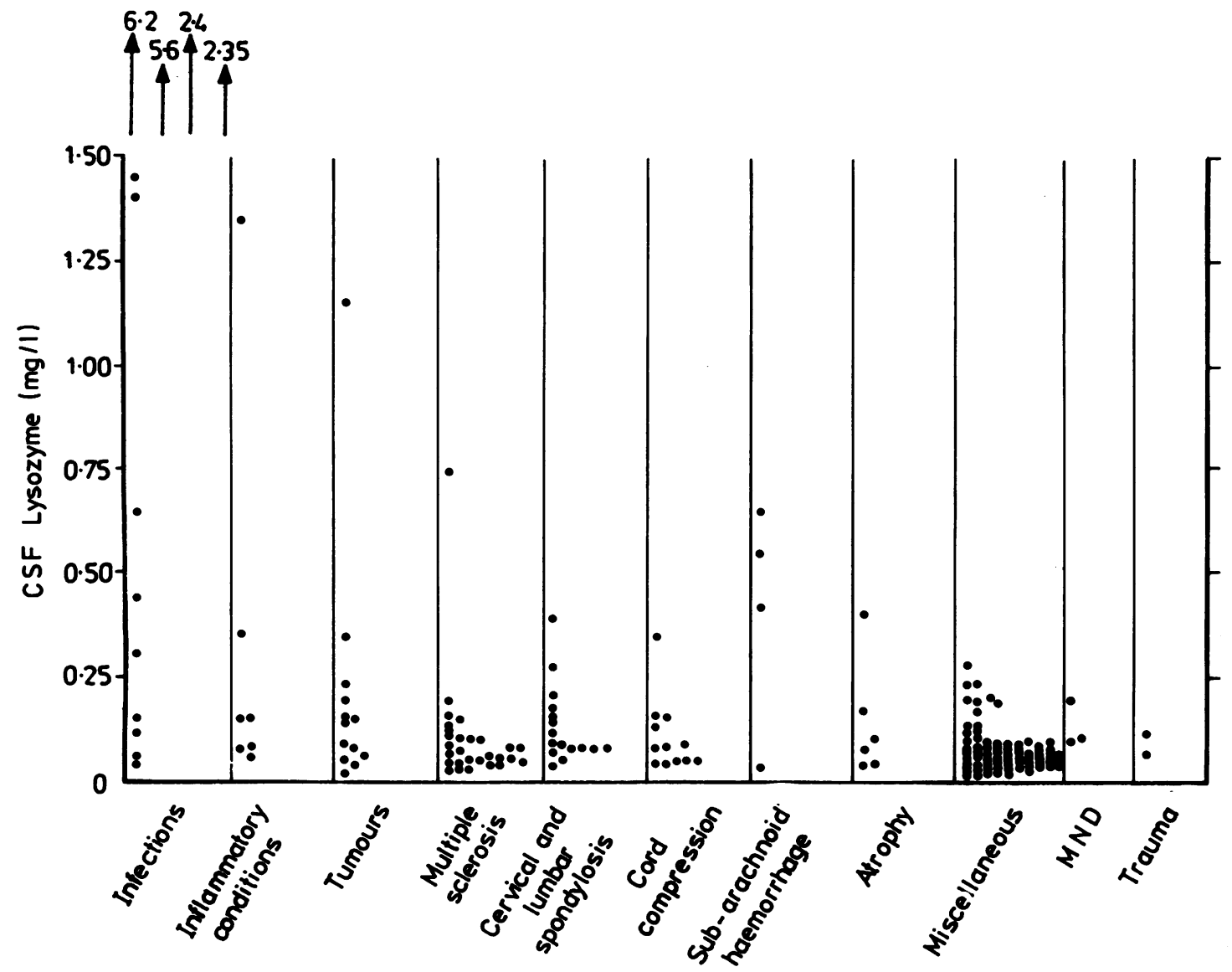

Fig 1 Lumbar CSF lysozyme levels in a spectrum of neurological diseases.

\section{Results}

CSF lysozyme levels of $0-0.2 \mathrm{mg} / 1$ were obtained in the disease control group of patients. Levels of CSF lysozyme were found within the above range in cases of cervical and lumbar spondylosis, motor neuron disease, cortical atrophy and miscellaneous neurological diseases (fig 1).

All cases of bacterial and fungal meningitis showed markedly elevated levels of lysozyme in the CSF, including cases of cryptococcal, candida, tuberculous meningitis, and meningovascular syphilis. Of five cases of viral meningitis and encephalitis studied, two had slightly elevated levels, although not of the same magnitude as found in cases of bacterial and fungal meningitis $(0.32$ and $0.44 \mathrm{mg} / \mathrm{l}$ ). A case of cerebral malaria had a marginally elevated level of $0.31 \mathrm{mg} / \mathrm{l}$. Two cases of bacterial meningitis and one of tuberculous meningitis were followed for periods of up to 77 days (fig 2).
Serially measured lysozyme levels generally showed a positive correlation with CSF protein and cell count and a strong negative correlation with glucose.

Elevated lysozyme levels were also found in various acute inflammatory conditions, including a case of post-traumatic spinal arachnoiditis. Elevated levels were not found in tumour cases except for one patient with a metastatic adenocarcinoma with spinal block and another patient with neurofibromatosis. Only one patient with multiple sclerosis with very acute symptoms had a raised level although a case of acute myelitis with a slightly elevated level may in fact have been due to this cause. A slight elevation of CSF lysozyme was found in one case of severe cerebral atrophy.

\section{Discussion}

Numerous variations in the nephelometric technique for the determination of lysozyme have been 

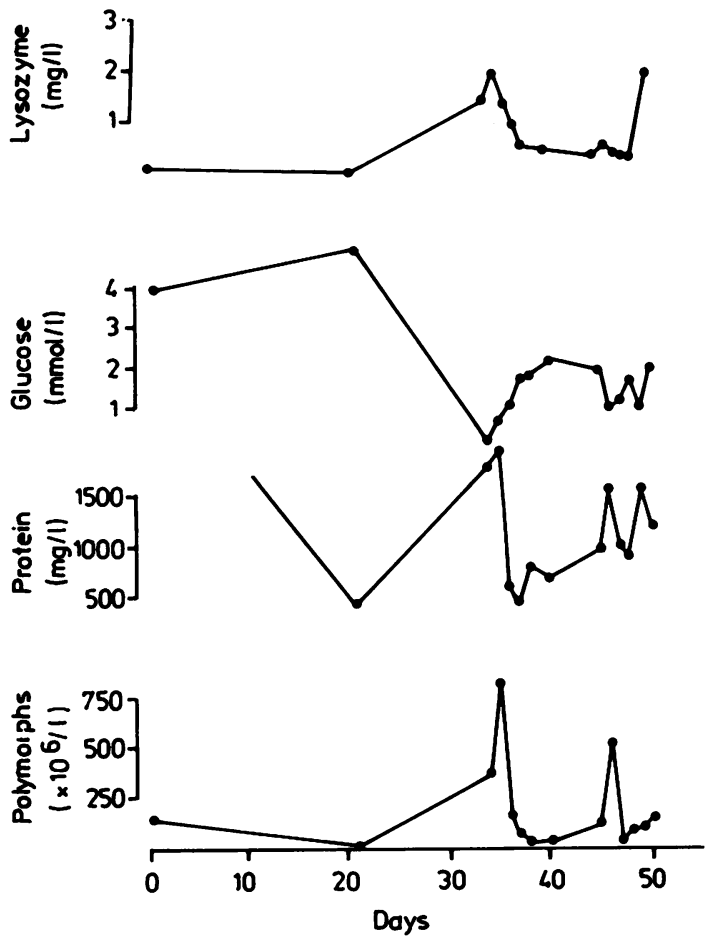

Fig 2 Serial estimations of lumbar CSF lysozyme, with cell counts, glucose and protein measurements in a case of bacterial meningitis in which the specific organism was not identified (Case No. 133).

described 9910 but many suffer from lack of sensitivity owing to the adoption of non-optimal assay conditions and have used egg white lysozyme as a standard which has a much lower catalytic activity than human lysozyme and slightly different optimum assay conditions.

The method has recently been reassessed ${ }^{8}$ and has been standardised with respect to buffer $\mathrm{pH}$ and molarity, wavelength, temperature and ratio of CSF to reagent volume, in order specifically to produce the most sensitive assay for the estimation of lysozyme in CSF. This technique has proved to be sufficiently sensitive to detect bacteriolytic activity in most CSF specimens so far examined, unlike the majority of previously described assays, and can be easily carried out at the same time as the routine estimation of glucose, protein and cells. A withinbatch coefficient of variaton of $1.9 \%$ at a lysozyme concentration of $1 \mathrm{mg} / \mathrm{l}, 5.5 \%$ at $0.1 \mathrm{mg} / \mathrm{l}$ and a detection limit of $0.02 \mathrm{mg} / \mathrm{l}$ have been obtained.

In this study we were able to confirm the considerable elevations of CSF lysozyme reported in cases of bacterial and tuberculous meningitis, but were unable to confirm the suggestion that CSF lysozyme estimation may be of diagnostic value in the detection of primary and metastatic tumours of the central nervous system. ${ }^{6}$ Lumbar puncture would in any case now be contra-indicated in many of the patients suffering from these conditions. ${ }^{\prime \prime}$

Single estimations of CSF lysozyme appeared to be as sensitive an indicator of bacterial meningitis as did combined estimations of glucose, protein and cell count. Estimation of lysozyme activity did not appear to be warranted in those cases where abnormal glucose and cell counts were clearly indicative of a bacterial meningitis. However, in cases where the CSF glucose level was normal or only marginally reduced and cell microscopy showed a lymphocytic or mixed cell population, CSF lysozyme estimation appeared to be useful in distinguishing viral from other forms of infection (table).

Serial estimations of CSF lysozyme in cases of bacterial and tuberculous meningitis showed a close positive correlation with cell count and an inverse relationship with CSF glucose levels. Levels of lysozyme decreased and glucose simultaneously increased towards normal in response to treatment. However, the therapeutic implications of changes in lysozyme levels in response to treatment must be

Table Discriminating value of elevated CSF lysozyme levels with normal or slightly elevated sugar and protein levels in individual patients with bacterial and fungal as opposed to viral meningitis and encephalitis

\begin{tabular}{|c|c|c|c|c|c|}
\hline Diagnosis & Neutrophils $\times 10^{\circ} / \mathrm{l}$ & Lymphocytes $\times 10^{\circ} / l$ & $\begin{array}{l}\text { Glucose mmolll } \\
N R=3 \cdot 3-4 \cdot 4\end{array}$ & $\begin{array}{l}\text { Protein } m g / l \\
N R=200-400\end{array}$ & $\begin{array}{l}\text { Lysozyme mg/l } \\
0-0.2\end{array}$ \\
\hline $\begin{array}{l}\text { Viral encephalitis } \\
\text { Meningitis (secondary }\end{array}$ & $\mathbf{0}$ & $\mathbf{0}$ & $3 \cdot 4$ & 270 & 0.04 \\
\hline $\begin{array}{l}\text { to infectious } \\
\text { mononucleosis) } \\
\text { Herpes simplex }\end{array}$ & $\mathbf{0}$ & 18 & $3 \cdot 3$ & 400 & $0 \cdot 12$ \\
\hline $\begin{array}{l}\text { encephalitis } \\
\text { Mild encephalitis } \\
\text { Cerebral malaria } \\
\text { Candida meningitis }\end{array}$ & $\begin{array}{r}0 \\
2 \\
0 \\
116\end{array}$ & $\begin{array}{r}64 \\
7 \\
5 \\
60\end{array}$ & $\begin{array}{l}4 \cdot 4 \\
3 \cdot 6 \\
4 \cdot 3 \\
2 \cdot 8\end{array}$ & $\begin{array}{l}600 \\
600 \\
480 \\
600\end{array}$ & $\begin{array}{l}0.44 \\
0.32 \\
0.31 \\
1 \cdot 4\end{array}$ \\
\hline $\begin{array}{l}\text { Meningovascular } \\
\text { syphilis }\end{array}$ & 5 & 30 & $3 \cdot 2$ & 1000 & 1.35 \\
\hline
\end{tabular}


interpreted with some caution since certain drugs have been shown to have a direct effect on lysozyme levels independent of any action on disease activity. ${ }^{12}$

The elevated lysozyme level found in one acute case of multiple sclerosis and in one other probable case is of interest and merits further study. This may be of added importance in view of the reports of elevated lysosomal enzyme levels in CSF from patients with multiple sclerosis and the suggestion that these may represent useful markers reflecting the immunopathogenesis of the condition..$^{13}$

These studies have confirmed previous observations that CSF lysozyme levels are useful in distinguishing viral from bacterial cases of meningitis and the improved method described in this paper would allow this estimation to be carried out rapidly and with a high degree of precision.

\section{References}

1 Osserman E. Lysozyme. New Engl J Med 1975; 292:424-5.

${ }^{2}$ Rabe E, Curnen E. The occurrence of lysozyme in the cerebrospinal fluid and serum of infants and children. J Pediatrics 1951;38:147-53.

${ }^{3}$ Gekle D, Kult J, Roth $R$. Lysozym und $\mathbf{B}_{2}-$ Microglobulin in liquor gesunder kinder und bei kin- dern mit erkrankungen des zentralnervensystems. Klin Wschr 1977;55:189-91.

${ }^{4}$ Pavlovichev SA. Immunological examination of the cerebrospinal fluid in the diagnosis of post-traumatic meningitis. Zh Vopr Neirokhir 1983;3:18-21.

${ }^{5}$ Grubbauer HM. Spinal fluid lysozyme levels in childhood meningitis. Monatsschr - Kinderheilkd 1980; 128:717-9.

- Newman J, Josephson A, Cacatian A, Tsang A. Spinalfluid lysozyme in the diagnosis of central nervous system tumours. Lancet 1974;2:756-7.

${ }^{7}$ Mason D, Roberts-Thomson P. Spinal fluid lysozyme in diagnosis of central nervous system tumours. Lancet 1974;2:952.

${ }^{8}$ Firth GB. Lysozyme. Thesis submitted in partial fulfilment of the MSc Degree. University of Surrey, 1976.

9 Prasad A, Litwack G. Measurement of the Lytic Activity of Lysozymes. Anal Biochem 1963;6:328-34.

${ }^{10}$ Litwack G. Photometric Determination of Lysozyme Activity. Proc Soc Exp Biol (NY) 1955;89:401-3.

"Pearce JMS. Hazards of Lumbar Puncture. Br Med J 1982;285: 1521.

12 Turton CWG, Grundy E, Firth G, Mitchell D, Rigden BG, Turner-Warwick M. Value of Measuring serum angiotensin 1 Converting Enzyme and Serum Lysozyme in the management of Sarcoidosis. Thorax 1979; 34:57-62.

${ }^{13}$ Cuzner ML, Davidson AN, Rudge P. Proteolytic enzyme activity in blood leukocytes and cerebrospinal fluid in multiple sclerosis. Ann Neurol 1978;4:337. 